\title{
Assessment of a landfill methane emission screening method using an unmanned aerial vehicle mounted thermal infrared camera - A field study
}

Fjelsted, Lotte; Christensen, A. G.; Larsen, J. E.; Kjeldsen, Peter; Scheutz, Charlotte

Published in:

Waste Management

Link to article, DOI:

10.1016/j.wasman.2018.05.031

Publication date:

2019

Document Version

Peer reviewed version

Link back to DTU Orbit

Citation $(A P A)$ :

Fjelsted, L., Christensen, A. G., Larsen, J. E., Kjeldsen, P., \& Scheutz, C. (2019). Assessment of a landfill methane emission screening method using an unmanned aerial vehicle mounted thermal infrared camera $-\mathrm{A}$ field study. Waste Management, 87, 893-904. https://doi.org/10.1016/j.wasman.2018.05.031

\section{General rights}

Copyright and moral rights for the publications made accessible in the public portal are retained by the authors and/or other copyright owners and it is a condition of accessing publications that users recognise and abide by the legal requirements associated with these rights.

- Users may download and print one copy of any publication from the public portal for the purpose of private study or research.

- You may not further distribute the material or use it for any profit-making activity or commercial gain

- You may freely distribute the URL identifying the publication in the public portal 
Assessment of a landfill methane emission screening method using an unmanned aerial vehicle mounted thermal infrared camera - a field study

Fjelsted, L. ${ }^{*}$, Christensen, A.G. ${ }^{\#}$, Larsen, J.E. . ${ }^{\#}$ Kjeldsen, P. ${ }^{*}$, Scheutz, C.

${ }^{\#}$ Niras A/S, Sortemosevej 19, DK-3450 Allerød, Denmark

${ }^{*}$ Department of Environmental Engineering, Technical University of Denmark, DK-2800 Kgs. Lyngby, Denmark

Corresponding author:

Lotte Fjelsted. Tel.: +45 60400 499; E-mail address: Ifj@niras.dk

\section{Abstract}

An unmanned aerial vehicle (UAV)-mounted thermal infrared (TIR) camera's ability to delineate landfill gas (LFG) emission hotspots was evaluated in a field test at two Danish landfills (Hedeland landfill and Audebo landfill). At both sites, a test area of $100 \mathrm{~m}^{2}$ was established and divided into about 100 measuring points. The relationship between LFG emissions and soil surface temperatures were investigated through four to five measuring campaigns, in order to cover different atmospheric conditions along with increasing, decreasing and stable barometric pressure. For each measuring campaign, a TIR image of the test area was obtained followed by the measurement of methane $\left(\mathrm{CH}_{4}\right)$ and carbon dioxide $\left(\mathrm{CO}_{2}\right)$ emissions at each measuring point, using a static flux chamber. At the same time, soil 
temperatures measured on the surface, at $5 \mathrm{~cm}$ and $10 \mathrm{~cm}$ depths, were registered. At the Hedeland landfill, no relationship was found between LFG emissions and surface temperatures. In addition, $\mathrm{CH}_{4}$ emissions were very limited, on average $0.92-4.52 \mathrm{~g} \mathrm{CH}_{4} \mathrm{~m}^{-2}$ $d^{-1}$, and only measureable on the two days with decreasing barometric pressure. TIR images from Hedeland did not show any significant temperature differences in the test area. At the Audebo landfill, an area with slightly higher surface temperatures was found in the TIR images, and the same pattern with slightly higher temperatures was found at a depth of 10 $\mathrm{cm}$. The main LFG emissions were found in the area with the higher surface temperatures. LFG emissions at Audebo were influenced significantly by changes in barometric pressure, and the average $\mathrm{CH}_{4}$ emissions varied between $111 \mathrm{~g} \mathrm{~m}^{-2} \mathrm{~d}^{-1}$ and $314 \mathrm{~g} \mathrm{~m}^{-2} \mathrm{~d}^{-1}$, depending on whether the barometric pressure gradient had increased or decreased, respectively. The temperature differences observed in the TIR images from both landfills were limited to between $0.7^{\circ} \mathrm{C}$ and $1.2^{\circ} \mathrm{C}$. The minimum observable $\mathrm{CH}_{4}$ emission for the TIR camera to identify an emission hotspot was $150 \mathrm{~g} \mathrm{CH}_{4} \mathrm{~m}^{-2} \mathrm{~d}^{-1}$ from an area of more than $1 \mathrm{~m}^{2}$.

\section{Keywords:}

Landfill gas; Surface flux; UAS; Drone; Remote sensing; IR

\section{Introduction}

The degradation of landfilled organic waste will inevitably generate landfill gas (LFG), containing mainly methane $\left(\mathrm{CH}_{4}\right)$ and carbon dioxide $\left(\mathrm{CO}_{2}\right)$. Methane is a potent greenhouse gas, and landfill $\mathrm{CH}_{4}$ emissions contribute to climate change (Bogner et al., 2008). Furthermore, $\mathrm{CH}_{4}$ emissions from landfills are often very inhomogeneous in nature and 
occur from localised hotspots (Röwer et al., 2011; Xu et al., 2014). To mitigate LFG emissions, knowledge about emission hotspots is necessary. Ground-based surface screening for locating emission hotspots, however, is very time-consuming and labour-intensive, as landfills are often several hectares in area and not always easily accessible. The common screening tools in use today are ground-based and employ different kinds of portable gas sensors; therefore, a screening tool based on remote sensing could potentially be more costefficient than what is currently available. Remote sensing measuring techniques such as the tracer dispersion method can be used to quantify total $\mathrm{CH}_{4}$ emissions from landfills (Mønster et al., 2014), but they do not provide information about specific emission hotspots. Alternative remote sensing methods include satellite images, which often have the disadvantage that the resolution in the image is too low to cover the high spatial resolution of the LFG emissions (Beaumont et al., 2014; lacoboaea and Petrescu, 2013; Yan et al., 2014). To delineate emission hotspots, a flexible screening tool that can cover high levels of spatial resolution is needed - and a screening tool based on an unmanned aerial system/vehicle (UAS/UAV) could be the solution.

Methane generation is an exothermic process that warms up LFG (up to $60^{\circ} \mathrm{C}$ ), and so emissions can potentially be seen as thermal anomalies at the surface of the landfill, when using a thermal infrared (TIR) camera, which, when mounted on a UAV, could potentially be an efficient screening tool, as a large area can be surveyed in a relatively short time, including areas which would normally be inaccessible by foot (Capodici et al., 2015; Lewis et al., 2003; Tanda et al., 2017).

Thermography, however, also has some limitations, in that results can be influenced by sunlight, ambient temperatures, wind, surface materials and distance between a sensor and 
the source (Lewis et al., 2003). Temperature differences in TIR images can thus appear without a LFG emission, whilst a LFG emission can take place without resulting in a temperature difference in a TIR image (Raco et al., 2005). As an example, an area exhibiting a higher temperature in a TIR image of landfill surfaces could be due to waste degradation in the underlying parts of the landfill and not necessarily connected to a higher emission rate (Raco et al., 2005). Microbial oxidation of LFG in the cover soil also results in higher topsoil temperatures.

Only few studies have tested thermography as a screening tool for LFG emission hotspots, and with varying findings (see Table 1 for an overview). Some studies have reported limited relations between LFG emissions and surface temperatures (Battaglini et al., 2013; Desideri et al., 2007; Lewis et al., 2003; Raco et al., 2005), while others have found the opposite (Capodici et al., 2015).

A UAV-mounted TIR camera's ability to delineate LFG emission hotspots was evaluated in this study through detailed investigations of LFG emissions, using static flux chambers, and surface temperatures at two Danish landfills with different characteristics. The primary objective was to study the relationship between LFG emissions and surface temperatures, and secondly to determine the minimum $\mathrm{CH}_{4}$ surface flux identifiable through thermography. To cover the spatial and temporal variability of the LFG emissions, measurements were conducted at about 100 points within a $100 \mathrm{~m}^{2}$ area and repeated four days at the first landfill and five days at the second landfill. 


\section{Material and methods}

To test the UAV-mounted TIR camera's ability to delineate LFG emission hotspots, two test sites were established at two Danish landfills (Hedeland landfill, near Roskilde, and Audebo landfill, near Holbæk).

\subsection{Test sites}

Hedeland landfill, Roskilde, Denmark. The landfill is located in an old gravel quarry and covers approximately 10 ha. About 2.9 million tons of mainly non-combustible waste was landfilled from 1979 to 2009. In the section where the test area was established, the top cover consists of 1 metre of soil, placed directly on top of the waste. Waste thickness differs between 20 to 40 metres. There is a gas collection system in parts of the landfill.

A surface screening campaign, to detect LFG emissions, was conducted in spring 2015 using a portable flame ionization detector (FID) (TVA1000B, Thermo Scientific, USA). A 100 $\mathrm{m}^{2}$ test area was established on an east-facing slope, where surface screening identified some of the most significant LFG emissions. The corners of the area were marked with aluminium plates (approximately 40x40 cm each) working as ground control points in the thermal images. Vegetation was cut down, and the test area was divided into $1 \times 1$ metre grids, giving 81 measuring points. After a new surface screening of the test area with an FID, 19 extra points were added, to ensure no emission hotspots were left out, resulting in a total of 100 measuring points, which were marked and their position located using a GPS (R8, Trimble, USA).

Next to the test area, four soil gas probes $(25 \mathrm{~mm}$ diameter, PVC casing with a $10 \mathrm{~cm}$ filter in the bottom) for temperature and pore gas sampling were installed at depths of 0.5 , 
1,2 and 2.7 metres, respectively. Four measuring campaigns were conducted in December 2015. The winter season was chosen, in order to eliminate the influence of vegetation and to maximise temperature contrast between the ambient air and the LFG. Four days of measurements were conducted, to cover different atmospheric conditions of both increasing and decreasing barometric pressure. Fig. 1 provides an overview of barometric pressure and atmospheric air temperature during the measuring period.

Audebo landfill, Holbæk, Denmark. Landfilling is still in progress at the Audebo landfill. The closed and covered section contains about 604,000 tons of waste, deposited from 1990 to 2009. The top cover consists of 1 metre of soil, placed directly on top of the waste. The waste layer is on average 11 metres thick and covers an area of 5.5 ha. The site has a gas collection system installed, but it has not been working efficiently for some years.

Surface screening, to detect LFG emissions from the closed section, was conducted in the summer 2015, using a portable FID. A test area of $100 \mathrm{~m}^{2}$ was established where the screening had identified some of the most significant surface emissions. The corners were marked using aluminium plates as ground control points. Vegetation was cut down, and the test area was divided into $1 \times 1$ metre grids. The surface of the test area was screened again with a portable $\mathrm{CH}_{4}$ detector (Laser One, Huberg, Italy), to ensure that no important emission hotspots inside the $100 \mathrm{~m}^{2}$ were missed. The screening resulted in 20 extra measuring points, resulting in 101 measuring points in total, which were marked and positioned using a GPS.

Next to the test area, four soil gas probes were installed at depths of $0.5,1,2$ and 2.5 metres, respectively ( $25 \mathrm{~mm}$ diameter, PVC casing with a $10 \mathrm{~cm}$ filter in the bottom). Five measuring campaigns were conducted in March 2016, to cover different atmospheric 
conditions of both increasing, decreasing and stable atmospheric pressure and to make it possible to study temporal variability of the emissions (Fig. 2). The measuring campaigns were conducted before the growing season started and while temperature contrasts in the ambient air and LFG were still at their maximum levels.

\subsection{Thermal infrared images}

Thermal infrared images of the test areas at the two landfills were captured using a thermal infrared camera (TIM 450 with a $38^{\circ}$ aperture angle lens, Micro Epsilon, Germany), which measured surface temperature with a system accuracy of $\pm 2^{\circ} \mathrm{C}$, in the temperature range relevant for this study, and a temperature resolution of $0.04^{\circ} \mathrm{C}$. The TIR camera had a geometric resolution of $382 \times 288$ pixel and worked in the spectral range $7.5-13 \mu \mathrm{m}$. TIR images were captured each morning, on the days of the measuring campaigns and before sunrise, thereby maximising temperature contrasts in the ambient air and the warm LFG.

Hedeland landfill is situated one kilometre from an airport, making it difficult to get permission to fly with a UAV; instead the TIR camera was placed at the top of the opposite slope at a distance of approximately 30 metres in a straight line. From this position, it was possible to capture the test area within one frame, thus eliminating the need to stitch the images together in a mosaic.

At Audebo landfill, TIR images were captured using the UAV flying at 20-25 metres above the ground, making it possible to capture the $100 \mathrm{~m}^{2}$ test area in one frame.

The TIR images were processed using the free software QGIS (Quantum GIS, version 2.18.2). The surface temperature at each measuring point registered in the TIR images was found from the average temperature of the 16 pixels approximately covering the same area 
(about $0.08 \mathrm{~m}^{2}$ ) as the static flux chamber used to measure LFG emissions (see section 2.4 about emission measurements).

\subsection{Temperature}

Soil temperatures were measured on the surface $(0 \mathrm{~cm})$, at $5 \mathrm{~cm}$ and $10 \mathrm{~cm}$ depths. Surface temperatures were registered using an infrared thermometer (ThermoSpot Pro, Laserliner, UK), measuring in the range $-40^{\circ} \mathrm{C}$ to $600^{\circ} \mathrm{C}$. Soil temperatures at $5 \mathrm{~cm}$ and $10 \mathrm{~cm}$ were measured using a penetration thermometer (testo 905-T1, Testo, Germany) in the range $-50^{\circ} \mathrm{C}$ to $350^{\circ} \mathrm{C}$. Both thermometers had an accuracy of $\pm 1^{\circ} \mathrm{C}$ in the temperature ranges found in this study and a resolution of $0.1^{\circ} \mathrm{C}$.

The temperature in the deeper layers was measured once every day in the four deepsoil gas probes next to the test areas, using a digital thermometer type $\mathrm{K}$ thermocouple (RS Pro 51 1-canal type $\mathrm{K}$, RS Components Ltd., UK) measuring in the range $-50^{\circ} \mathrm{C}$ to $1300^{\circ} \mathrm{C}$, with an accuracy of $\pm 0.2 \%$ (reading $+1^{\circ} \mathrm{C}$ ) and a resolution of $0.1^{\circ} \mathrm{C}$.

\subsection{Landfill gas surface emissions}

LFG emissions were measured using a static flux chamber and a 1312 Photoacoustic multi-gas monitor (Innova, LumaSense Technologies, Denmark), registering the accumulation of $\mathrm{CH}_{4}$ and $\mathrm{CO}_{2}$ in the chamber at each measuring point. The multi-gas monitor was calibrated for two ranges for both $\mathrm{CH}_{4}$ and $\mathrm{CO}_{2}\left(\mathrm{CH}_{4}\right.$ : 0.4-9.99 ppm and 999-19,900 ppm; $\mathrm{CO}_{2}: 1.5-800 \mathrm{ppm}$ and $\left.800-9,990 \mathrm{ppm}\right)$, and the detection limits were $0.4 \mathrm{ppm}$ for $\mathrm{CH}_{4}$ and $1.5 \mathrm{ppm}$ for $\mathrm{CO}_{2}$. The flux of $\mathrm{CH}_{4}$ and $\mathrm{CO}_{2}$ was calculated from: 


$$
Q=\frac{d C}{d t} \times \frac{V}{A}
$$

where $\mathrm{dC} / \mathrm{dt}$ is change in the concentration of the respective gas over the time the measurement took place, $V$ is the volume of the flux chamber $\left(0.016 \mathrm{~m}^{3}\right)$ and $A$ is the area covered by the chamber $\left(0.078 \mathrm{~m}^{2}\right)$. At each measuring point, $\mathrm{dC} / \mathrm{dt}$ was calculated based on five gas concentration measurements recorded during a time period of approximately three minutes. The flux chamber was pushed a few centimetres into the soil to ensure sealing between surface and flux chamber. The detection limit of the flux measurements was \pm 0.05 $\mathrm{g} \mathrm{m}^{-2} \mathrm{~d}^{-1}$ (Scheutz et al., 2011).

The composition of the LFG, before passage through the cover, was measured in the deep probes next to the test areas, using a portable gas analyser (Biogas 5000, Geotechnical Instruments, UK). The gas analyser measured $\mathrm{CH}_{4}, \mathrm{CO}_{2}$ and Oxygen $\left(\mathrm{O}_{2}\right)$ in the concentration range $0-100 \%$ (vol.) for $\mathrm{CH}_{4}$ and $\mathrm{CO}_{2}$ and $0-25 \%$ (vol.) for $\mathrm{O}_{2}$, and instrument accuracy was $\pm 0.5 \%$ (vol.) for $\mathrm{CH}_{4}$ and $\mathrm{CO}_{2}$ up to $70 \%$ and $60 \%$, respectively and $\pm 1.5 \%$ (vol.) in the highconcentration ranges to $100 \%$ (vol.). Oxygen was measured with an accuracy of $\pm 1 \%$ (vol.).

The barometric pressure gradient was calculated for the period starting 3.5 hours before the first flux measurement and ending 1 hour after the last flux measurement.

The average emission from the test areas were calculated from the 100/101 measurements, using the simple natural neighbour interpolation in Maplnfo Vertical Mapper, version 3.7.1. 


\section{Results and discussion}

\subsection{Temperature}

The temperature profiles for the upper 3 metres of waste and soil cover clearly show an upward thermal gradient at both landfills. At a depth of 2.5 - 3 metres, the temperature was around $16^{\circ} \mathrm{C}$ at Hedeland and $14^{\circ} \mathrm{C}$ at Audebo. At 0.5 metres, the temperature varied between 7 to $9^{\circ} \mathrm{C}$ and 5 to $6^{\circ} \mathrm{C}$ at Hedeland and Audebo, respectively. Ambient air temperatures varied from $5-9^{\circ} \mathrm{C}$ at Hedeland and $6-10^{\circ} \mathrm{C}$ at Audebo (Fig. 3).

The typical soil temperature in Denmark at 2 metres below the surface under short-cut grass in December was around $8^{\circ} \mathrm{C}$ and in March around $5^{\circ} \mathrm{C}$ (Jensen and Jensen, 1999), so the deeper soil temperatures at both landfills were $4-5^{\circ} \mathrm{C}$ higher than what would be expected in regular soil.

On measurement days, the ambient air temperature increased during the day, resulting in an increase in the soil temperature in the upper 5 to $10 \mathrm{~cm}$ diminishing the effect of the warm LFG migrating through the soil cover.

For all four campaigns, TIR images from the Hedeland landfill showed no thermal anomalies, and the temperature difference between the 100 measuring points was only between 0.7 and $1.1^{\circ} \mathrm{C}$ (Fig. $4 \mathrm{~A}$ and Fig. SM1 in Supplementary Information (SM)). Temperature differences in the TIR images from the Audebo landfill were in the same range ( 0.8 to $1.2^{\circ} \mathrm{C}$ ) as those at Hedeland landfill, but at the Audebo landfill all images consistently showed a pattern, with a higher temperature in a specific part of the test area (Fig. 4B and Fig. SM4 in SM). 


\subsection{Landfill gas emissions}

The measuring campaigns were repeated for four and five days at both landfills, to cover different atmospheric conditions of increasing, decreasing and stable barometric pressure. LFG emissions were influenced by changes in the barometric pressure (Fig. 5). Note the differences in the scale of the $y$-axis between Fig. 5A and Fig. 5B. At both test sites, the average $\mathrm{CH}_{4}$ emission from the test area, obtained by interpolating the flux measurements from the 100/101 measuring points, increased with a decrease in barometric pressure. At the Audebo landfill, a linear trend was observed between $\mathrm{CH}_{4}$ emissions and changes in barometric pressure and at the Hedeland landfill $\mathrm{CH}_{4}$ emissions were only observed during measurement periods with decreasing barometric pressure.

At the Hedeland landfill, $\mathrm{CH}_{4}$ emissions measured at the measuring points were in general very low (most of them below detection or even negative). Negative $\mathrm{CH}_{4}$ emissions indicated that methanotrophs in the landfill cover soil were oxidising atmospheric $\mathrm{CH}_{4}$, a phenomenon frequently observed at landfills (e.g. Bogner et al., 1995; Scheutz et al., 2008, 2003). Only in two of the four measuring campaigns (December $8^{\text {th }}$ and December $10^{\text {th }}$ ) were $\mathrm{CH}_{4}$ emissions detected and only at a few measuring points, though not at the same measuring point on the two days. During both December $8^{\text {th }}$ and December $10^{\text {th }}$, the barometric pressure decreased. On December $8^{\text {th }}$, the average $\mathrm{CH}_{4}$ emission from the 100 measuring points was $0.92 \mathrm{~g} \mathrm{CH}_{4} \mathrm{~m}^{-2} \mathrm{~d}^{-1}$ (with the largest emission measured at a single point of $62.1 \mathrm{~g} \mathrm{CH}_{4} \mathrm{~m}^{-2} \mathrm{~d}^{-1}$ ), measured during a pressure decrease of $0.50 \mathrm{hPa} \mathrm{h}^{-1}$, while on December $10^{\text {th }}$, the average $\mathrm{CH}_{4}$ emission was $4.52 \mathrm{~g} \mathrm{CH}_{4} \mathrm{~m}^{-2} \mathrm{~d}^{-1}$ (with the largest emission in a single point of $290 \mathrm{~g} \mathrm{CH}_{4} \mathrm{~m}^{-2} \mathrm{~d}^{-1}$ ) measured during a pressure decrease of $0.36 \mathrm{hPa} \mathrm{h}^{-1}$ 
(Fig.5A). On the other two measuring days (December $9^{\text {th }}$ and December $15^{\text {th }}$ ), the barometric pressure increased $\left(0.58 \mathrm{hPa} \mathrm{h}^{-1}\right.$ and $0.64 \mathrm{hPa} \mathrm{h}^{-1}$, respectively), and no $\mathrm{CH}_{4}$ emission was detected at any measuring point. The reason for the limited detection of LFG compared to previous investigations in the area could be that the soil was saturated with water because of high amounts of rain in the month preceding the measuring campaigns in this study. In November and December 2015, the accumulated precipitation in the region was $145 \mathrm{~mm}$ and $93 \mathrm{~mm}$, respectively and the historical normal average precipitation for November and December (from 1961 to 1990) was $60 \mathrm{~mm}$ and $55 \mathrm{~mm}$, respectively (DMI, 2015).

Carbon dioxide emissions from the test area at the Hedeland landfill were between 0 (or even negative) and $180 \mathrm{~g} \mathrm{CO}_{2} \mathrm{~m}^{-2} \mathrm{~d}^{-1}$. Carbon dioxide emissions from a Danish meadow, measured over 3 years, showed $\mathrm{CO}_{2}$ emissions between $0 \mathrm{~g} \mathrm{CO}_{2} \mathrm{~m}^{-2} \mathrm{~d}^{-1}$ and $10 \mathrm{~g} \mathrm{CO}_{2} \mathrm{~m}^{-2} \mathrm{~d}^{-1}$ in the winter season (Herbst et al., 2013). Measurements from a Danish grassland about 10 $\mathrm{km}$ from Hedeland landfill showed annual average ecosystem respiration of $5730 \mathrm{~g} \mathrm{CO}_{2} \mathrm{~m}^{-2}$ $\mathrm{y}^{-1}$, corresponding to $15.7 \mathrm{~g} \mathrm{CO}_{2} \mathrm{~m}^{-2} \mathrm{~d}^{-1}$ on average (Gilmanov et al., 2007). This might indicate that $\mathrm{CO}_{2}$ emissions from the test area at Hedeland landfill were caused not only by respiration of the ecosystem, but also by emission of LFG (either by direct emission of $\mathrm{CO}_{2}$ from LFG and/or indirectly by $\mathrm{CO}_{2}$ generated by $\mathrm{CH}_{4}$ oxidation).

Raw gas composition in a nearby borehole was 31.2 vol. $\% \mathrm{CH}_{4}, 16.8$ vol. $\% \mathrm{CO}_{2}$ and 0.4 vol. $\% \mathrm{O}_{2}$ resulting in a ratio between $\mathrm{CH}_{4}$ and $\mathrm{CO}_{2}$ in the raw gas of 1.85 . In comparison the $\mathrm{CH}_{4} / \mathrm{CO}_{2}$ ratio of the $\mathrm{LFG}$ emitted from the landfill surface was 0.18 on average, thereby indicating that $\mathrm{CH}_{4}$ was oxidised in the top cover. 
Compared to the Hedeland landfill, $\mathrm{CH}_{4}$ emissions at the Audebo landfill test site were higher, with single emission hotspots of up to over $14 \mathrm{~kg} \mathrm{CH}_{4} \mathrm{~m}^{-2} \mathrm{~d}^{-1}$. The average emissions of the 101 measuring points in the test area varied between $111 \mathrm{~g} \mathrm{CH}_{4} \mathrm{~m}^{-2} \mathrm{~d}^{-1}$ and $314 \mathrm{~g} \mathrm{CH}_{4}$ $\mathrm{m}^{-2} \mathrm{~d}^{-1}$. Similar to the Hedeland landfill, emissions were influenced by changes in barometric pressure. The highest average emissions of $314 \mathrm{~g} \mathrm{CH}_{4} \mathrm{~m}^{-2} \mathrm{~d}^{-1}$ and $649 \mathrm{~g} \mathrm{CO}_{2} \mathrm{~m}^{-2} \mathrm{~d}^{-1}$ were obtained during a decrease in barometric pressure of $0.33 \mathrm{hPa} \mathrm{h}^{-1}$, while the lowest average emissions (111 $\mathrm{g} \mathrm{CH}_{4} \mathrm{~m}^{-2} \mathrm{~d}^{-1}$ and $216 \mathrm{~g} \mathrm{CO}_{2} \mathrm{~m}^{-2} \mathrm{~d}^{-1}$ ) were measured during a pressure increase $\left(0.46 \mathrm{hPa} \mathrm{h}^{-1}\right)$ (Fig. 5B).

Raw gas composition at the Audebo landfill measured in the deepest of the four soil gas probes was 43 vol. $\% \mathrm{CH}_{4}, 31$ vol. $\% \mathrm{CO}_{2}$ and 0 vol. $\% \mathrm{O}_{2}$.

Landfill $\mathrm{CH}_{4}$ emission rates between $60 \mathrm{~g} \mathrm{~m}^{-2} \mathrm{~d}^{-1}$ and 16,600 $\mathrm{g} \mathrm{m}^{-2} \mathrm{~d}^{-1}$ were reported in the literature (Table 1), and $\mathrm{CH}_{4}$ emissions measured at the Audebo landfill were in the same range (between $0 \mathrm{~g} \mathrm{CH}_{4} \mathrm{~m}^{-2} \mathrm{~d}^{-1}$ to $14572 \mathrm{~g} \mathrm{CH}_{4} \mathrm{~m}^{-2} \mathrm{~d}^{-1}$ ).

The spatial variability of the LFG emissions at the Audebo landfill was high. More than $85 \%$ of the total $\mathrm{CH}_{4}$ emissions from the test site were emitted from less than $10 \%$ of the test site's area (Fig. 6). The ten measuring points with the highest emission varied across the five measuring days, while the measuring point with the highest emission was not the same on all measuring days.

The total $\mathrm{CH}_{4}$ emission from the Audebo landfill was measured using the tracer gas dispersion method at $9.0 \pm 1.7 \mathrm{~kg} \mathrm{CH}_{4} \mathrm{~h}^{-1}$ (Fredenslund et al., 2015). Using the interpolated data, the total emission of $\mathrm{CH}_{4}$, from the $100 \mathrm{~m}^{2}$ test area at the Audebo landfill, was calculated at between $0.46 \mathrm{~kg} \mathrm{~h}^{-1}$ and $1.3 \mathrm{~kg} \mathrm{~h}^{-1}$, depending on barometric pressure conditions. The $100 \mathrm{~m}^{2}$ accounted for less than $1 \%$ of the 5.5 ha landfill's surface area but up 
to $20 \%$ of the total $\mathrm{CH}_{4}$ emissions across the site. In the literature, examples were found where $50 \%$ of the total $\mathrm{CH}_{4}$ emissions emanated from less than $6 \%$ of the total landfill area (Gonzalez-Valencia et al., 2015).

\subsection{Relationship between surface emissions and temperature}

Soil temperatures at 0 and $-5 \mathrm{~cm}$ were affected by the ambient air temperature and solar radiation (Fig. 7Error! Reference source not found.), so the effects of the emission of warm LFG were masked. Soil temperatures measured at $-10 \mathrm{~cm}$ were more stable, and so these were used in the comparison between temperature and LFG surface emissions.

For the Hedeland landfill, no significant relationship was found between soil temperature at $-10 \mathrm{~cm}$ and LFG surface emissions. The measuring points with the highest emissions did not correlate with measuring points exhibiting the highest temperature (Fig. $8 \mathrm{~A}$ and Fig. $\mathrm{SM} 3$ in $\mathrm{SM})$. In general, the surface temperature varied between $5^{\circ} \mathrm{C}$ and $7^{\circ} \mathrm{C}$ except on the last measuring day (December $15^{\text {th }}$ ), when the surface temperature was only

$3-4^{\circ} \mathrm{C}$. TIR images from Hedeland landfill did not show any significant temperature differences on the surface of the test area (Fig. 9), which was the case for all four measuring days (Fig. SM2 in SM). On the first day, a temperature difference of only $0.7-0.8^{\circ} \mathrm{C}$ was found in the TIR images between the 100 measuring points, and on the last day, a temperature difference of up to $1.1^{\circ} \mathrm{C}$ was found.

TIR images from the Audebo landfill showed temperature differences between the 101 measuring points in the same range $\left(0.8-1.2^{\circ} \mathrm{C}\right)$ as the TIR images from the Hedeland landfill, but they consistently showed an area with a slightly higher temperature than the rest of the test area. The major part of the LFG emission from the test site was observed to 
occur from this area (Fig. 10 and Fig. SM5 in SM). Comparing the temperatures from the TIR image with the emissions of $\mathrm{CH}_{4}$ and $\mathrm{CO}_{2}$ showed no relationship between temperatures and emissions, using observations from individual measuring points (surface fluxes and average temperatures based on 16 TIR pixels) (Fig. 11). However, the highest emissions were seen in the area with the higher TIR-based temperatures (Fig. 10 and Fig. SM5 in SM). Comparing the TIR image with the interpolated temperatures measured at $-10 \mathrm{~cm}$ showed the same pattern with higher temperatures in the area where the main part of the LFG emission was measured (Fig. 8B and Fig. SM6 in SM and Fig. 10 and Fig. SM5 in SM). The consistent pattern of higher surface temperatures measured by both TIR images and at $-10 \mathrm{~cm}$ using a soil temperature probe indicated, that the higher TIR-based temperatures was not due to measurement bias caused by variation in emissivity of the test area's surface.

Methane emissions in the same ranges as those found at the Audebo landfill are reported in Raco et al. (2005) and Battaglini et al. (2013) for a landfill in Legoli, Italy. Here, $\mathrm{CH}_{4}$ fluxes between $61 \mathrm{~g} \mathrm{~m}^{-2} \mathrm{~d}^{-1}$ to $1346 \mathrm{~g} \mathrm{~m}^{-2} \mathrm{~d}^{-1}$ and below detection limit to $16,640 \mathrm{~g} \mathrm{~m}^{-2} \mathrm{~d}^{-}$ ${ }^{1}$ were reported, as well as temperature differences in the TIR images of up to $8^{\circ} \mathrm{C}$, which is substantially higher than the temperature differences found at the Audebo landfill. TIR images were captured from a hill next to the landfill and $\mathrm{CH}_{4}$ fluxes were measured using a static flux chamber. The highest $\mathrm{CH}_{4}$ fluxes were observed in the proximity of wells and drainage systems (Battaglini et al., 2013; Raco et al., 2005). Three out of seven emission areas were identified in TIR images with the used configuration.

Temperature differences of up to $14^{\circ} \mathrm{C}$ on the surface of a landfill in Genoa (Italy) were found by Tanda et al. (2017) with the use of a UAV-mounted TIR camera. The authors did not measure the direct surface emission of $\mathrm{CH}_{4}$ but estimated the $\mathrm{CH}_{4}$ flux based on a steady- 
state energy balance, using identified surface temperatures (as a measure for the heat emitted to the atmosphere) and knowledge about heat produced in the degradation process.

Capodici et al. (2015) found a good relationship between $\mathrm{CH}_{4}$ flux, measured with a static flux chamber, and ground temperature, obtained using a UAV-mounted TIR camera, in a field study at a Sicilian landfill (in Italy) with a final permanent multilayer cover. Fluxes of $\mathrm{CH}_{4}$ up to $1330 \mathrm{~g} \mathrm{CH}_{4} \mathrm{~m}^{-2} \mathrm{~d}^{-1}$ were measured, which are similar to what was found at the Audebo landfill. The difference between the maximum and minimum temperature in the TIR image showed in the paper is about $30^{\circ} \mathrm{C}$. The field study was conducted on a landfill capped with a liner and LFG emissions concentrated in the connections between the liner and the LFG collection wells, where faults in the liner appeared. Capodici et al. (2015) concluded that a good correlation between $\mathrm{CH}_{4}$ emission and ground temperature could be established.

Temperature contrast from $3.7^{\circ} \mathrm{C}$ to $23.4^{\circ} \mathrm{C}$ was found by Madruga et al. (2007), where the largest contrast of $23.4^{\circ} \mathrm{C}$ was from a LFG collection pipe and not related to a LFG leak or emission. Methane surface concentrations up to approximately 6 vol.\% was detected, but not all thermal anomalies was related to a LFG surface emission. Madruga et al. (2007) concluded that the thermography can be used as a screening tool to detect areas that need further investigation.

\subsection{Factors influencing the use of the thermal infrared images}

The use of TIR imagery as a screening tool for LFG emission hotspots has some limitations. First, it can be expected that a certain LFG flux is needed to heat the surface sufficiently to result in a surface temperature anomaly meaning that there is a lower 
threshold for when an emission can be recorded using TIR. This is obviously linked to the performance capabilities of the applied TIR camera (resolution, aperture lens angle, etc.) and test conditions (measuring height, weather conditions, etc.). In spite of the temperature difference recorded at both Hedeland and Audebo landfills (but especially at Hedeland) being rather low $\left(<1.1^{\circ} \mathrm{C}\right)$ they were higher than the resolution of the TIR camera applied, so it is not likely that the lack of relationship between temperature and surface emission was caused by measurement error. Another thing that could influence the heating of the surface caused by LFG emission is the temperature of the LFG. LFG temperatures can be up to $60^{\circ} \mathrm{C}$ (Hanson et al., 2010) but depend on the gas generation in the landfill body and thus the amount of disposed degradable waste. In Denmark, there has been a ban on landfilling of combustible waste since 1997, resulting in relatively low LFG generation rates and probably lower LFG temperatures compared to other sites receiving municipal solid waste. This could explain the relative small surface temperature difference observed on the two Danish landfills in comparison to the studies reported in the literature (cf. Table 1), which were most likely carried out at more traditional landfills receiving organic waste and thus had higher LFG production and higher temperatures. This then also explains why emissions at Audebo landfill were comparable to emissions measured in the studies reported in Table 1 but did not result in a significant surface temperature increase as the generated LFG was simply less warm at the Danish site.

A number of factors, other than emissions of warm LFG, can cause temperature differences resulting in measurement bias, which was thoroughly investigated in Lewis et al. (2003). Other processes generating heat can increase the surface temperature, for instance microbial oxidation of $\mathrm{CH}_{4}$ in the soil cover or respiration in compost based landfill biocovers. 
The difference in the ratio between $\mathrm{CH}_{4}$ and $\mathrm{CO}_{2}$ in raw gas and the emission can indicate if $\mathrm{CH}_{4}$ oxidation has taken - or is taking - place in the soil cover. At the Audebo landfill, raw gas had a $\mathrm{CH}_{4} / \mathrm{CO}_{2}$ ratio of 1.49 , and for approximately $30 \%$ of the measuring points, the $\mathrm{CH}_{4} / \mathrm{CO}_{2}$ ratio in the $\mathrm{LFG}$ emission was almost the same as for the raw gas, thereby indicating that no $\mathrm{CH}_{4}$ oxidation was taking place why it is unlikely that the recorded elevated temperatures were biased by heat generation from $\mathrm{CH}_{4}$ oxidation (Fig. 12).

Measurement bias can also be caused by variability in emissivity of different surfaces. Different vegetation and soil conditions on the surface, having different emissivity, will cause temperature anomalies in TIR images. For instance, Battaglini et al. (2013) found that a recently disturbed area resulted in a positive thermal anomaly in TIR images, and they found no LFG emissions in the area. At the Audebo landfill, the main part of the area with the highest $\mathrm{CH}_{4}$ emissions, and the highest temperatures based on TIR images, had no or very scarce vegetation and bare, darker ground. It can be difficult to determine the cause of measured temperature differences, i.e. whether it is due to measurement bias caused by variability in surface emissivity or by heat generation by other processes than warm LFG such as microbial $\mathrm{CH}_{4}$ oxidation.

Some of the most significant hotspots at the Audebo landfill appeared as small, localised holes in the ground and were not distinguishable in the TIR images as single hotspots (Fig. 13 and Fig. 14), most likely due to the small area distribution. Measuring point HS10 (Fig. 13) might be approximately $3 \times 3$ pixels in the TIR images, while point HS5 (Fig. 14) was less than a pixel. HS14 (Fig. 14) was an area in which the soil had slid and cracked and the LFG emission appeared on the side of this slide, and thus the actual hole was on the vertical part of the slide and not visible from the air. This indicates that the flight height of 
the UAV should be as low as possible, in order to maximise the size of any hotspots in the TIR images and minimise the distance between the sensor and the surface. Another reason for the missing anomaly at HS10 could be because the warmer LFG was emitted directly from the bottom of the hole and the LFG was thus not in contact with the surface soil and therefore not able to warm up the surrounding soil.

The temperature contrast between surface and ambient air should be maximized to get the best results of the TIR images. Therefore the best time of the day for capturing TIR images is in the morning, before sunrise (Capodici et al., 2015; Lewis et al., 2003). This was verified by the results from the Audebo landfill (Fig. 7Error! Reference source not found.), since the temperature increased during the day in the upper $10 \mathrm{~cm}$ of the soil as an effect of solar radiation.

Lewis et al. (2003) found that temperature differences between LFG leak points and background detected with a TIR camera was greatly reduced under windy conditions (wind speed of $11.3 \mathrm{~m} \mathrm{~s}^{-1}$ compared to a wind speed of $1.0 \mathrm{~m} \mathrm{~s}^{-1}$ ).

Solar radiation will also give an uneven heating of the surface potentially causing a measurement bias in the TIR images.

The time of year could also have an influence on the temperature differences registered in the TIR images, both in terms of vegetation (reduce measurement bias) and temperature contrast between LFG and ambient air. Furthermore, vegetation will be denser in the growing season, making it more difficult to see true surface temperatures in the TIR images. Thus, the winter season is the best time to screen for surface LFG emissions with a TIR and at the same time maximise temperature contrast between LFG and ambient air. 
The investigations in this study indicate that an emission of at least $150 \mathrm{~g} \mathrm{CH}_{4} \mathrm{~m}^{-2} \mathrm{~d}^{-1}$ is necessary and that the emission area needs to be more than $1 \mathrm{~m}^{2}$ for the TIR camera to identify an potential emission hotspot (Fig. 10 and Fig. SM5 in SM).

\section{Conclusion and perspectives}

An evaluation of an unmanned aerial vehicle (UAV)-mounted thermal infrared (TIR) camera's ability to delineate landfill gas (LFG) emission hotspots showed that the method has some potential, albeit in the right conditions. In this study, the method was tested at two Danish landfills. In Denmark, there has been a ban on landfilling of combustible waste since 1997, resulting in less generation of LFG and probably lower LFG temperatures compared to other sites containing waste with a higher content of organic matter. This study showed that the method could work under Danish conditions if the emission hotspot was at least $150 \mathrm{~g} \mathrm{CH}_{4} \mathrm{~m}^{-2} \mathrm{~d}^{-1}$ and had a spatial distribution of at least $1 \mathrm{~m}^{2}$.

Larger temperature differences on the surface of landfills, observed using a TIR camera, were reported in the literature compared to what was observed in this study. At the same time, the LFG emissions reported were similar to what were observed in this study, which could indicate that the method could have greater potential at municipal solid waste landfills generating high levels of LFG.

\section{Acknowledgments}

The work presented herein was funded by an industrial PhD project hosted by Niras A/S and The Technical University of Denmark (DTU). The PhD project was funded by the Innovation Fund Denmark (Project ref. no.: 4135-00011B). The authors wish to thank ARGO 
for providing access to the Audebo and Hedeland landfills. Thanks also to Jens Frederiksen (NIRAS), Katrine Led (NIRAS), Benjamin Hunner (NIRAS), Henrik Kjøller (NIRAS) and Anders

Fredenslund (DTU Environment) for their assistance with performance in the field measurements. Thanks to our UAV pilot, Søren Rolin (NIRAS) for help with the images at the Audebo landfill and to Casper Børgesen (NIRAS) for help with the image processing.

\section{Supplementary materials}

Supplementary materials with TIR images and emission data from measuring campaigns, which are not presented in this paper, are available online.

\section{References}

Battaglini, R., Raco, B., Scozzari, A., 2013. Effective monitoring of landfills: flux measurements and thermography enhance efficiency and reduce environmental impact. J. Geophys. Eng. 10, 64002. doi:10.1088/1742-2132/10/6/064002

Beaumont, B., Radoux, J., Defourny, P., 2014. Assessment of airborne and spaceborne thermal infrared remote sensing for detecting and characterizing landfills. Waste Manag. Environ. VII 180, 237-248.

Bogner, J., Pipatti, R., Hashimoto, S., Diaz, C., Mareckova, K., Diaz, L., Kjeldsen, P., Monni, S., Faaij, a., Qingxian Gao, Tianzhu Zhang, Mohammed Abdelrafie Ahmed, Sutamihardja, R.T.M., Gregory, R., 2008. Mitigation of global greenhouse gas emissions from waste: conclusions and strategies from the Intergovernmental Panel on Climate Change (IPCC) Fourth Assessment Report. Working Group III (Mitigation). Waste Manag. Res. 26, 1132. doi:10.1177/0734242X07088433 
Bogner, J., Spokas, K., Burton, E., Sweeney, R., Corona, V., 1995. Landfills as atmospheric methane sources and sinks. Chemosphere 31, 4119-4130. doi:10.1016/13522310(96)81661-X

Capodici, M., Ciraolo, G., Trapani, D.D.I., Viviani, G., 2015. Remote Sensing Analysis Coupled To Field Measurements for the Evaluation of Methane Emissions From a Landfill Site : a Case Study, in: Proceedings Sardinia 2015, Fifteenth International Waste Management and Landfill Symposium.

Desideri, U., Leonardi, D., Proietti, S., 2007. Application of Infrared Thermography To Study Behaviour of Biogas Captation Wells, in: Proceedings Sardinia 2007, Eleventh International Waste Management and Landfill Symposium.

DMI, 2015. Vejrarkiv [WWW Document]. Danmarks Meteorol. Inst. URL http://www.dmi.dk/vejr/arkiver/vejrarkiv/ (accessed 3.27.18).

Fredenslund, A.M., Delre, A., Scheutz, C., 2015. Måling af den totale metanemission fra Audebo Miljøcenter.

Gilmanov, T.G., Soussana, J.F., Aires, L., Allard, V., Ammann, C., Balzarolo, M., Barcza, Z., Bernhofer, C., Campbell, C.L., Cernusca, A., Cescatti, A., Clifton-Brown, J., Dirks, B.O.M., Dore, S., Eugster, W., Fuhrer, J., Gimeno, C., Gruenwald, T., Haszpra, L., Hensen, A., Ibrom, A., Jacobs, A.F.G., Jones, M.B., Lanigan, G., Laurila, T., Lohila, A., G.Manca, Marcolla, B., Nagy, Z., Pilegaard, K., Pinter, K., Pio, C., Raschi, A., Rogiers, N., Sanz, M.J., Stefani, P., Sutton, M., Tuba, Z., Valentini, R., Williams, M.L., Wohlfahrt, G., 2007. Partitioning European grassland net ecosystem $\mathrm{CO} 2$ exchange into gross primary productivity and ecosystem respiration using light response function analysis. Agric. Ecosyst. Environ. 121, 93-120. doi:10.1016/j.agee.2006.12.008 
Gonzalez-Valencia, R., Magana-Rodriguez, F., Cristóbal, J., Thalasso, F., 2015. Hotspot detection and spatial distribution of methane emissions from landfills by a surface probe method. Waste Manag. 55, 299-305. doi:10.1016/j.wasman.2016.03.004

Hanson, J.L., Yesiller, N., Oettle, N.K., 2010. Spatial and Temporal Temperature Distributions in Municipal Solid Waste Landfills. J. Environ. Eng. 136, 804-814. doi:10.1061/(ASCE)EE.1943-7870.0000202

Herbst, M., Friborg, T., Schelde, K., Jensen, R., Ringgaard, R., Vasquez, V., Thomsen, A.G., Soegaard, H., 2013. Climate and site management as driving factors for the atmospheric greenhouse gas exchange of a restored wetland. Biogeosciences 10, 39-52. doi:10.5194/bg-10-39-2013

lacoboaea, C., Petrescu, F., 2013. Landfill monitoring using remote sensing: a case study of Glina, Romania. Waste Manag. Res. 31, 1075-1080. doi:10.1177/0734242X13487585 Jensen, H.E., Jensen, S.E., 1999. Jordvarme og jordtemperatur (kapitel 8), in: Jordfysik Og Jordbrugsmeteorologi - Det Fysiske Miljø for Plantevækst.

Lewis, A.W., Yuen, S.T.S., Smith, A.J.R., 2003. Detection of gas leakage from landfills using infrared thermography - applicability and limitations. Waste Manag. Res. 21, 436-447. doi:10.1177/0734242X0302100506

Madruga, F.J., Munoz, J.M., Gonzalez, D. a., Tejero, J.I., Cobo, A., Gil, J.L., Conde, O.M., Lopez-Higuera, J.M., 2007. Field test of infrared thermography applied to biogas controlling in landfill sites. Proc. SPIE 6541, 65411B-65411B-6. doi:10.1117/12.719366

Mønster, J.G., Samuelsson, J., Kjeldsen, P., Rella, C.W., Scheutz, C., 2014. Quantifying methane emission from fugitive sources by combining tracer release and downwind measurements - a sensitivity analysis based on multiple field surveys. Waste Manag. 34, 
1416-28. doi:10.1016/j.wasman.2014.03.025

Raco, B., Scozzari, A., Guidi, M., Lelli, M., Lippo, G., 2005. Comparison of Two Non-Invasive Methodologies To Monitor Diffuse Biogas Emissions From MSW Landfills Soil : a Case Study, in: Proceedings Sardinia 2005, Tenth International Waste Management and Landfill Symposium.

Röwer, I.U., Geck, C., Gebert, J., Pfeiffer, E.-M., 2011. Spatial variability of soil gas concentration and methane oxidation capacity in landfill covers. Waste Manag. 31, 926-34. doi:10.1016/j.wasman.2010.09.013

Scheutz, C., Bogner, J., Chanton, J., Blake, D., Morcet, M., Kjeldsen, P., 2003. Comparative Oxidation and Net Emissions of Methane and Selected Non-Methane Organic Compounds in Landfill Cover Soils. Environ. Sci. Technol. 37, 5150-5158. doi:10.1021/es034016b

Scheutz, C., Bogner, J., Chanton, J.P., Blake, D., Morcet, M., Aran, C., Kjeldsen, P., 2008. Atmospheric emissions and attenuation of non-methane organic compounds in cover soils at a French landfill. Waste Manag. 28, 1892-1908. doi:10.1016/j.wasman.2007.09.010

Scheutz, C., Fredenslund, A.M., Chanton, J., Pedersen, G.B., Kjeldsen, P., 2011. Mitigation of methane emission from Fakse landfill using a biowindow system. Waste Manag. 31, 1018-28. doi:10.1016/j.wasman.2011.01.024

Tanda, G., Migliazzi, M., Chiarabini, V., Cinquetti, P., 2017. Application of close-range aerial infrared thermography to detect landfill gas emissions: a case study. J. Phys. Conf. Ser. 796, 12016. doi:10.1088/1742-6596/796/1/012016

Xu, L., Lin, X., Amen, J., Welding, K., McDermitt, D., 2014. Impact of changes in barometric 
pressure on landfill methane emission. Global Biogeochem. Cycles 28, 679-695. doi:10.1002/2013GB004571

Yan, W.Y., Mahendrarajah, P., Shaker, A., Faisal, K., Luong, R., Al-Ahmad, M., 2014. Analysis of multi-temporal landsat satellite images for monitoring land surface temperature of municipal solid waste disposal sites. Environ. Monit. Assess. 186, 8161-8173. doi:10.1007/s10661-014-3995-z 
2 Table 1: Previous studies investigating the relationship between surface temperatures using TIR and landfill gas emissions.

\begin{tabular}{|c|c|c|c|c|c|c|}
\hline \multirow[b]{2}{*}{ Reference } & \multirow[b]{2}{*}{ Location } & \multicolumn{2}{|c|}{ Method } & \multicolumn{2}{|c|}{ Findings } & \multirow[b]{2}{*}{ General findings } \\
\hline & & $\begin{array}{l}\text { Surface } \mathrm{CH}_{4} \\
\text { measurement }\end{array}$ & $\begin{array}{l}\text { Temperature } \\
\text { measurement }\end{array}$ & $\begin{array}{l}\text { Surface } \mathrm{CH}_{4} \text { flux or } \\
\text { conc. recorded }\end{array}$ & $\begin{array}{l}\text { Temperature } \\
\text { difference } \\
\text { recorded }\end{array}$ & \\
\hline $\begin{array}{l}\text { (Tanda et } \\
\text { al., 2017) }\end{array}$ & Italy & $\begin{array}{l}\text { No measurements. } \\
\text { Calculated from a } \\
\text { steady-state energy } \\
\text { balance model based on } \\
\text { measured surface } \\
\text { temperatures }\end{array}$ & $\begin{array}{l}\text { TIR (FLIR T460, FLIR } \\
\text { A65, and FLUKE Ti } \\
\text { 300), UAV-mounted }\end{array}$ & $\begin{array}{l}0.025-0.06 \mathrm{~m}^{3} \text { biogas } \\
\mathrm{m}^{-2} \mathrm{~h}^{-1} \\
\left(402-965 \mathrm{~g} \mathrm{CH}_{4} \mathrm{~m}^{-2} \mathrm{~d}^{-}\right. \\
\left.{ }^{1}\right)\end{array}$ & $3.5-14.1^{\circ} \mathrm{C}$ & $\begin{array}{l}\text { LFG emissions were calculated from surface temperatures } \\
\text { measured using TIR. The study did not measure surface } \mathrm{CH}_{4} \\
\text { emissions. } \\
\text { The authors conclude that close-range aerial TIR is a reliable } \\
\text { approach for monitoring urban landfills combined with the } \\
\text { presented calculation it can provide a preliminary estimation of the } \\
\text { methane production potential of the disposed waste. }\end{array}$ \\
\hline $\begin{array}{l}\text { (Capodici } \\
\text { et al., } \\
\text { 2015) }\end{array}$ & Italy & $\begin{array}{l}\mathrm{CH}_{4} \text { fluxes were } \\
\text { measured using static } \\
\text { flux chamber }\end{array}$ & $\begin{array}{l}\text { TIR (Optris } 450 \text { LW), } \\
\text { UAV-mounted }\end{array}$ & $\begin{array}{l}0.001-15.4 \mathrm{mgCH}_{4} \mathrm{~m}^{-} \\
{ }^{2} \mathrm{~s}^{-1} \\
\left(0.0864-1331 \mathrm{~g} \mathrm{~m}^{-2} \mathrm{~d}^{-}\right. \\
\left.{ }^{1}\right)\end{array}$ & $\begin{array}{l}\text { About } 30^{\circ} \mathrm{C} \\
\text { (read from max } \\
\text { and min in image) }\end{array}$ & $\begin{array}{l}\text { No information about location of } \mathrm{CH}_{4} \text { flux measurements in the TIR } \\
\text { image is provided. } \\
\text { The authors conclude that a good relationship between surface } \\
\text { temperatures and } \mathrm{CH}_{4} \text { emissions were found for before-sunrise } \\
\text { images. }\end{array}$ \\
\hline $\begin{array}{l}\text { (Battaglini } \\
\text { et al., } \\
\text { 2013) }\end{array}$ & Italy & $\begin{array}{l}\mathrm{CH}_{4} \text { fluxes were } \\
\text { measured using static } \\
\text { flux chamber }\end{array}$ & $\begin{array}{l}\text { TIR (FLIR), Handheld } \\
\text { Images captured } \\
\text { from an opposite hill }\end{array}$ & $\begin{array}{l}\text { b.d.I. }-1040 \mathrm{~mol} \mathrm{~m}^{-2} \mathrm{~d}^{-1} \\
\text { (b.d.I. }-16640 \mathrm{~g} \mathrm{~m}^{-2} \mathrm{~d}^{-1} \text { ) }\end{array}$ & $\begin{array}{l}2-7,5^{\circ} \mathrm{C} \\
\text { (read from image) }\end{array}$ & $\begin{array}{l}\text { No information if the measured fluxes are related to areas in TIR } \\
\text { images with higher temperatures. } \\
\text { Concludes that the combination of thermography and direct surface } \\
\text { flux measurements gives new information to the landfill manager. }\end{array}$ \\
\hline $\begin{array}{l}\text { (Desideri } \\
\text { et al., } \\
\text { 2007) }^{*}\end{array}$ & & No measurement & $\begin{array}{l}\text { TIR (Thermovision } \\
\text { 900), handheld }\end{array}$ & No measurement & $\begin{array}{l}5-12^{\circ} \mathrm{C} \\
\text { (read from image - } \\
\text { showing gas } \\
\text { collection pipes) }\end{array}$ & $\begin{array}{l}\text { The objective was to evaluate the behaviour of gas collection well } \\
\text { at different pressure levels. IR images showed that heating of the } \\
\text { soil around the well was influenced by pumping conditions. }\end{array}$ \\
\hline $\begin{array}{l}\text { (Madruga } \\
\text { et al., } \\
\text { 2007)* }\end{array}$ & Spain & $\begin{array}{l}\text { Surface } \mathrm{CH}_{4} \\
\text { concentration (infrared } \\
\text { absorption gas analyser) }\end{array}$ & $\begin{array}{l}\text { TIR, handheld. } \\
\text { Distance } 0.5 \mathrm{~m} \text { to } 12 \\
\mathrm{~m}\end{array}$ & b.d.l. $-6.3 \%$ & $3.7-23.4^{\circ} \mathrm{C}$ & $\begin{array}{l}\text { LFG emissions were measured at cracks and gas collection wells. } \\
\text { Relationship possible only under the right conditions. Efficient } \\
\text { screening tool if the temperature differences are at least five } \\
\text { degrees. Thermography can be used as a screening tool but not as a } \\
\text { precise tool to detect LFG emissions. }\end{array}$ \\
\hline $\begin{array}{l}\text { (Raco et } \\
\text { al., 2005) }\end{array}$ & Italy & $\begin{array}{l}\mathrm{CH}_{4} \text { fluxes were } \\
\text { measured using static } \\
\text { flux chamber }\end{array}$ & $\begin{array}{l}\text { TIR, Handheld } \\
\text { Images captured } \\
\text { from an opposite hill }\end{array}$ & $\begin{array}{l}3.83-84.1 \mathrm{~mol} \mathrm{~m}^{-2} \mathrm{~d}^{-1} \\
\left(61.3-1346 \mathrm{~g} \mathrm{~m}^{-2} \mathrm{~d}^{-1}\right)\end{array}$ & $\begin{array}{l}5-8^{\circ} \mathrm{C} \\
\text { (read from image) }\end{array}$ & $\begin{array}{l}\text { Three out of } 7 \text { flux areas were identified in TIR images with the used } \\
\text { configuration. }\end{array}$ \\
\hline $\begin{array}{l}\text { (Lewis et } \\
\text { al., 2003) }\end{array}$ & Australia & $\begin{array}{l}\text { Surface } \mathrm{CH}_{4} \\
\text { concentration (infrared } \\
\text { absorption gas analyser) }\end{array}$ & $\begin{array}{l}\text { TIR }(320 \times 240 \text { pixel } \\
\text { image resolution } \\
\left.\text { and } 24^{\circ} \times 18^{\circ}\right) \\
\text { Handheld. } \\
\text { Distance } 2-15 \\
\text { meter. }\end{array}$ & $\begin{array}{l}\text { 1) } 4.35 \% \text { (no sun) } \\
\text { 1) } 0.03 \% \text { (windy) } \\
\text { 2) } 5.75 \% \\
\text { 3) } 5.67 \% \\
\text { 4) } 11.3 \% \\
\text { 5) } 10 \%\end{array}$ & $\begin{array}{l}\text { 1) } 16^{\circ} \mathrm{C} \text { (no sun) } \\
\text { 1) } 2.5^{\circ} \mathrm{C} \text { (windy) } \\
\text { 2) } 7.4^{\circ} \mathrm{C} \text { (no sun) } \\
\text { 3) } 9^{\circ} \mathrm{C} \\
\text { 4) } 14.2^{\circ} \mathrm{C} \text { (low } \\
\text { ambient temp.) } \\
\text { 5) } 5-9^{\circ} \mathrm{C}\end{array}$ & $\begin{array}{l}\text { TIR is capable of detection landfill gas leaks under certain } \\
\text { circumstances, but there are some limitations including weather } \\
\text { conditions (e.g. light, wind and ambient air temperature), nature of } \\
\text { ground surface and distance between sensor and source. } \\
\text { The technique can only be used as a screening tool and not as a } \\
\text { precise tool to detect LFG leaks. }\end{array}$ \\
\hline
\end{tabular}


$3 *$ Conference proceeding,

\#Peer-reviewed

$4 \quad{ }^{1}$ Unit indicates if it is flux $\left[\mathrm{g} \mathrm{m}^{-2} \mathrm{~d}^{-1}\right.$ ] or concentration [vol. \%] measurements; b.d.I. = below detection limit 
6

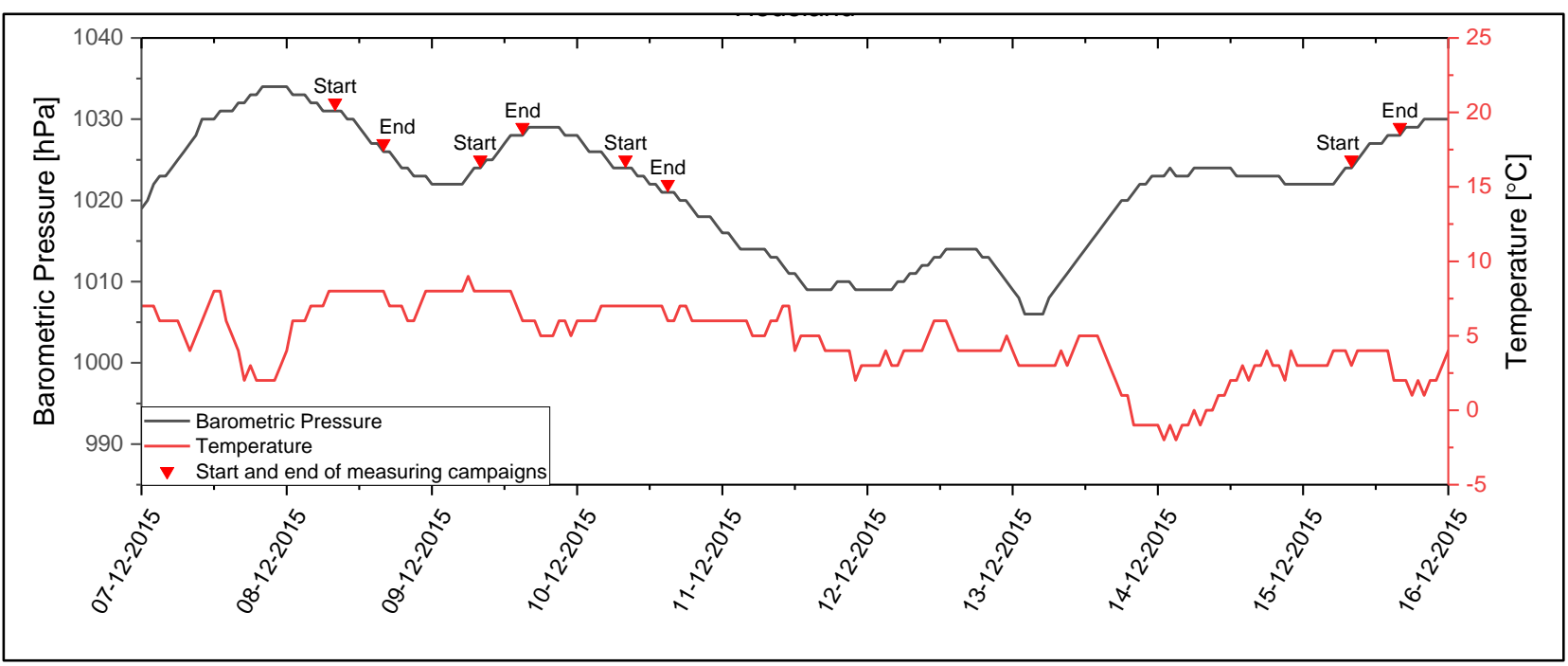

8 Fig. 1. Barometric pressure and ambient air temperature on the days around the four measuring

9 campaigns at the Hedeland landfill in December 2015. The start and end of each measuring day at the landfill are marked on the graph for barometric pressure. 


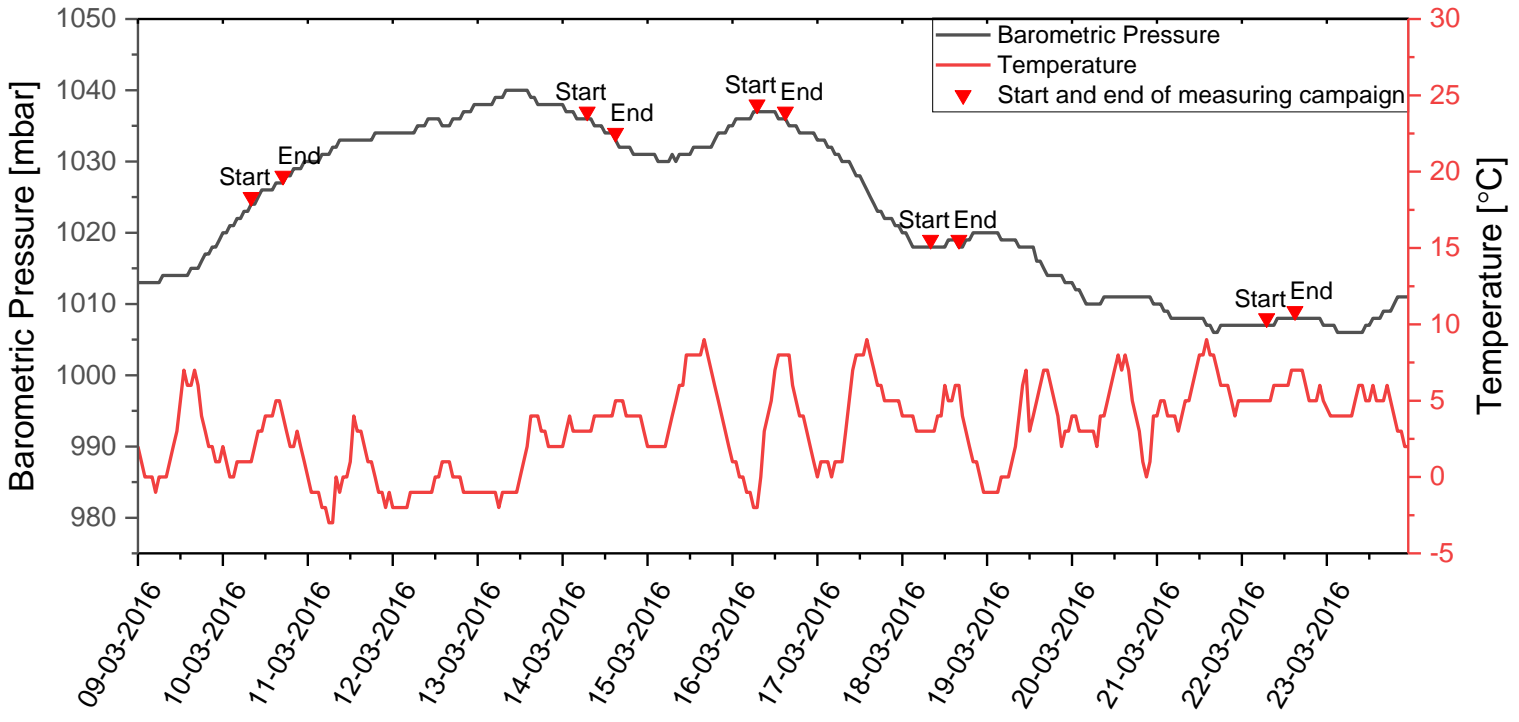

Fig. 2. Barometric pressure and ambient air temperature on the days around the five measuring campaigns at the Audebo landfill in March 2016. The start and end of each measuring day at the landfill are marked at the graph for barometric pressure. 


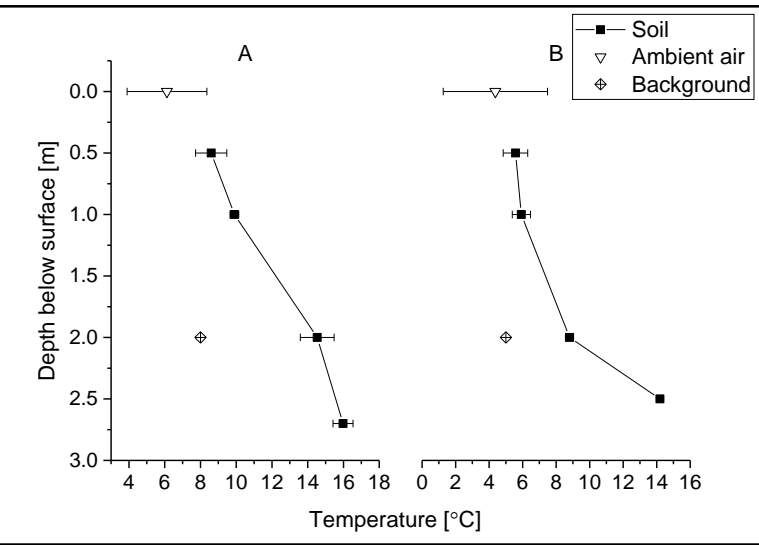

Fig.3. Temperature profile over the upper 3 metres of waste and soil cover at A: Hedeland landfill and B: Audebo landfill. Temperatures are the average measurement each day for the given depth. Temperature at $0 \mathrm{~m}$ is the average of the ambient air temperature during the measurement campaigns. Error bars indicate the standard deviation of the measured temperatures. Background is typical soil temperatures in Denmark in the same month as the measurement campaigns at the

23 given depth. 

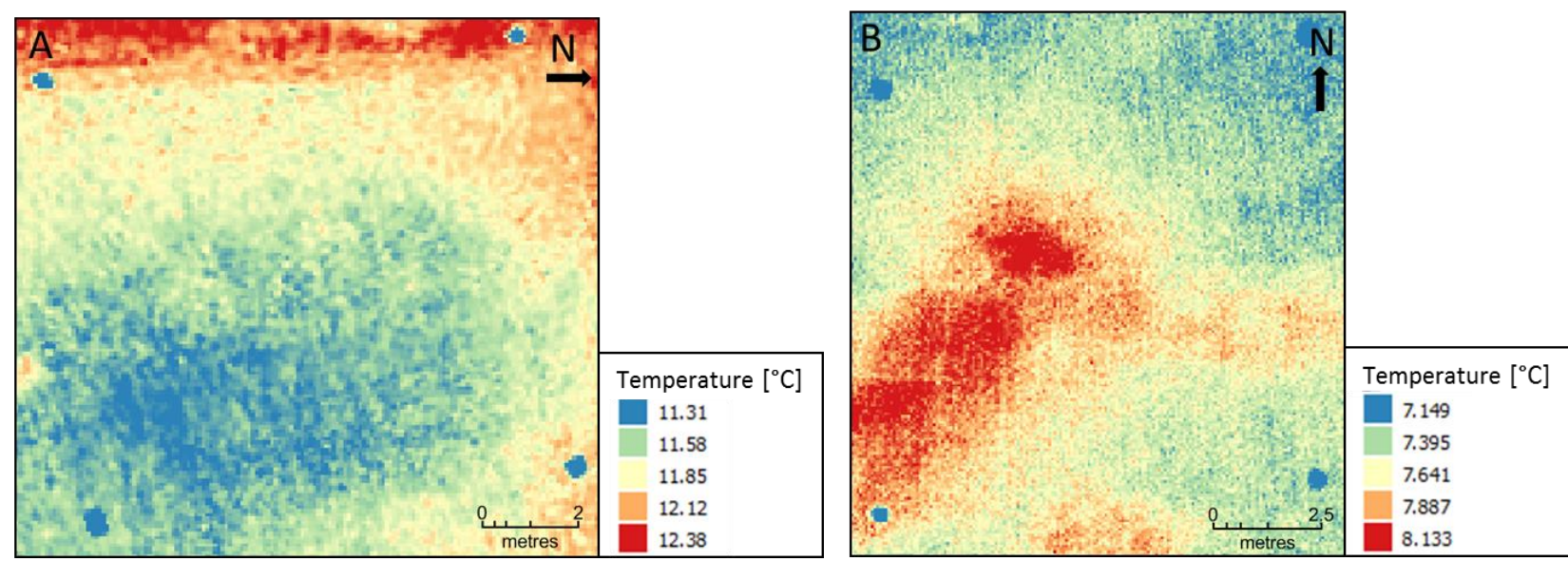

26 Fig. 4. TIR image of the test areas at A: Hedeland landfill, $10^{\text {th }}$ December 2015, and B: Audebo

27 landfill, $14^{\text {th }}$ March 2016. In both A and B, the cold areas in the corners are the ground control

28 points (aluminium plates) marking the corners of the test areas. The test area at Hedeland was

29 placed on a slope, and the warmer area in the western part of image A was a flat area at the top of

30 the hill and at a different angle to the TIR camera. 


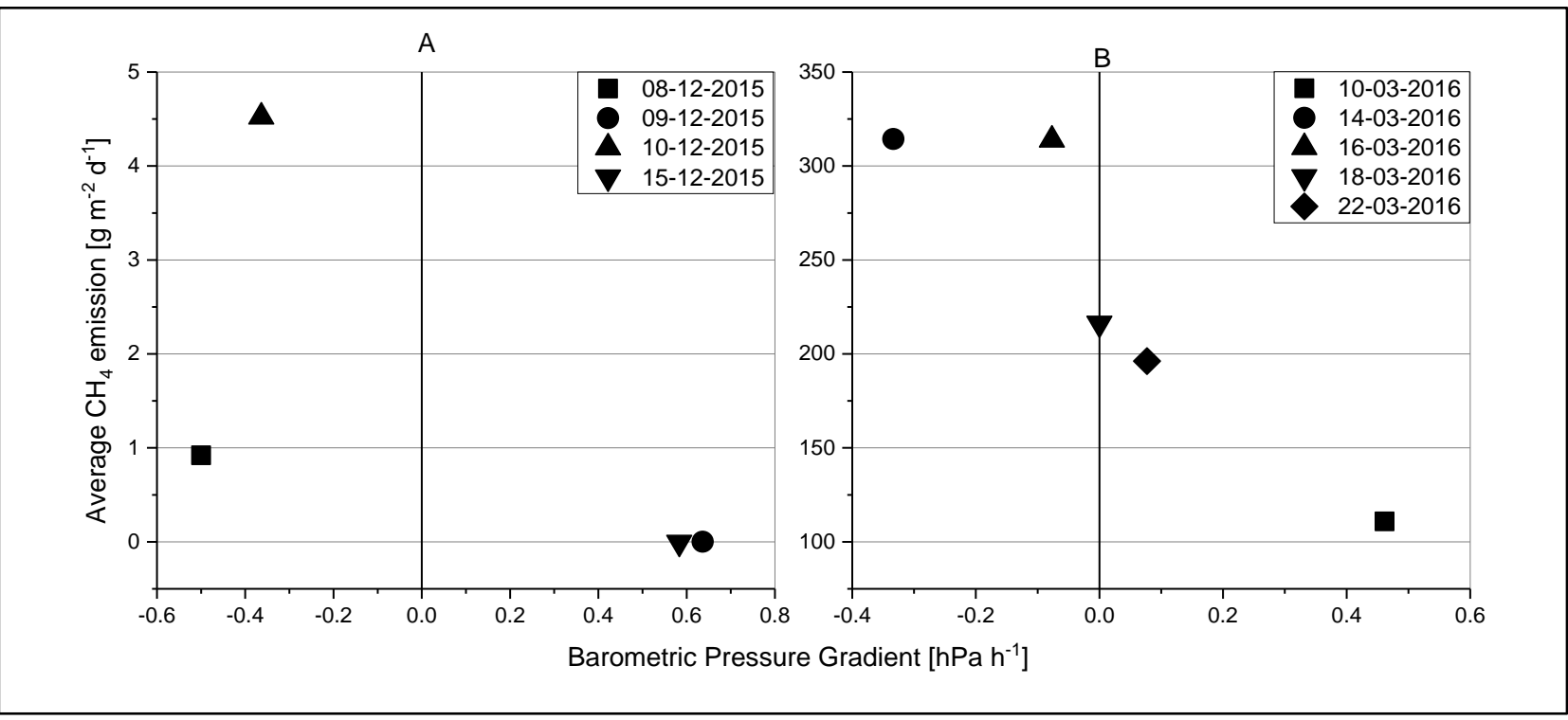

32

33 Fig.5. Average $\mathrm{CH}_{4}$ emissions of the $100 / 101$ measuring points in the test areas at A: Hedeland

34 landfill and B: Audebo landfill versus the barometric pressure gradient at each of the four and five 35 measuring campaigns, respectively. 


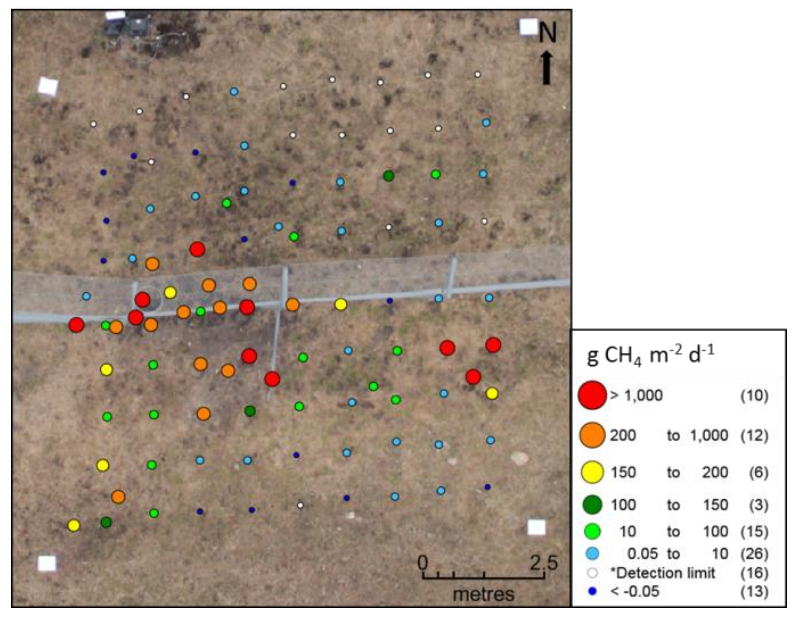

38 Fig.6. Aerial photo of the test area at Audebo landfill captured from the UAV. The coloured dots

39 represent measured $\mathrm{CH}_{4}$ emissions $\left[\mathrm{g} \mathrm{m}^{-2} \mathrm{~d}^{-1}\right.$ ] from March $14^{\text {th }} 2016$. Numbers in brackets are the

40 number of observations in each range. *Detection limit of the flux chamber measurements was

$41 \pm 0.05 \mathrm{~g} \mathrm{~m}^{-2} \mathrm{~d}^{-1}$.

42 


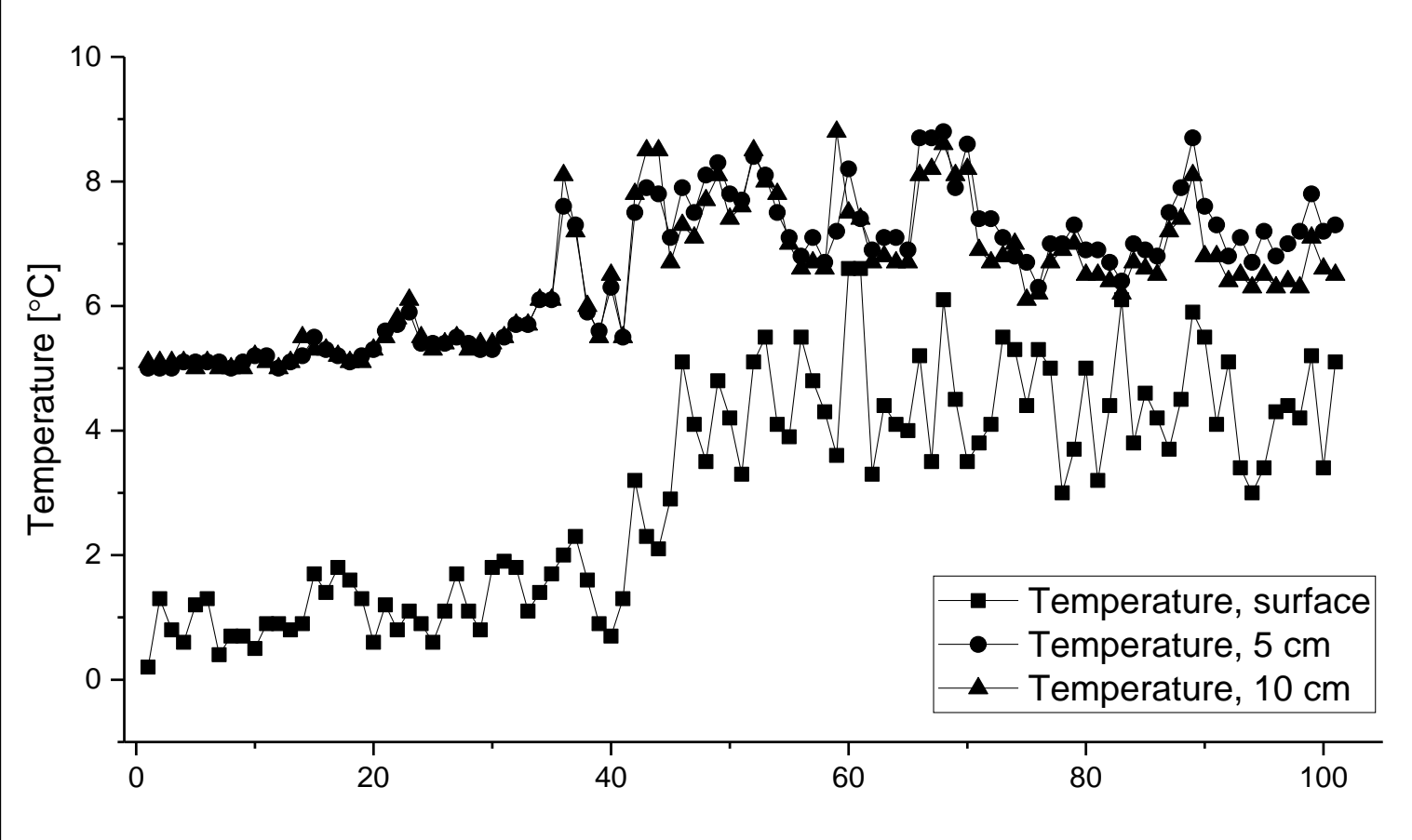

44 Fig. 7: Temperature in the upper $10 \mathrm{~cm}$ of soil in the test area at the Audebo landfill, March $22^{\text {nd }}$,

452016 , at each of the 101 measuring points. The first measurement was at 7.30 am and the last one 46 at 2:00 pm. 

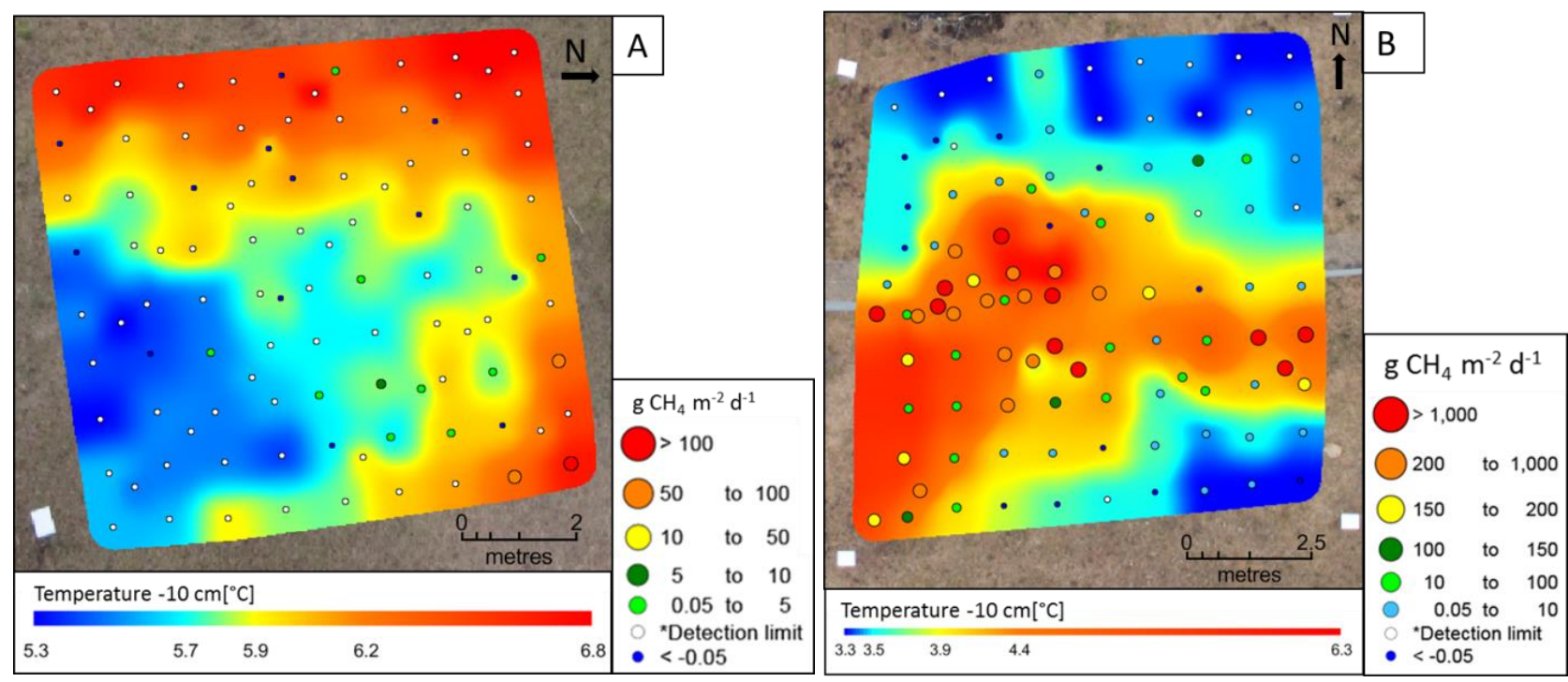

Fig.8. Methane emissions (coloured dots) $\left[\mathrm{g} \mathrm{m}^{-2} \mathrm{~d}^{-1}\right]$ versus soil temperature at $-10 \mathrm{~cm}\left[{ }^{\circ} \mathrm{C}\right]$ at $\mathrm{A}$ :

Hedeland landfill (December $\left.10^{\text {th }}, 2015\right)$ and B: Audebo landfill (March $\left.14^{\text {th }}, 2016\right)$. The numbers in

51 the temperature legend represent the quartiles of the temperature measurements. Note that in A, the largest temperature difference is $1.5^{\circ} \mathrm{C}$ and for $\mathrm{B}$ it is $3^{\circ} \mathrm{C}$. ${ }^{*}$ Detection limit of the flux chamber

53 measurements was $\pm 0.05 \mathrm{~g} \mathrm{~m}^{-2} \mathrm{~d}^{-1}$. 


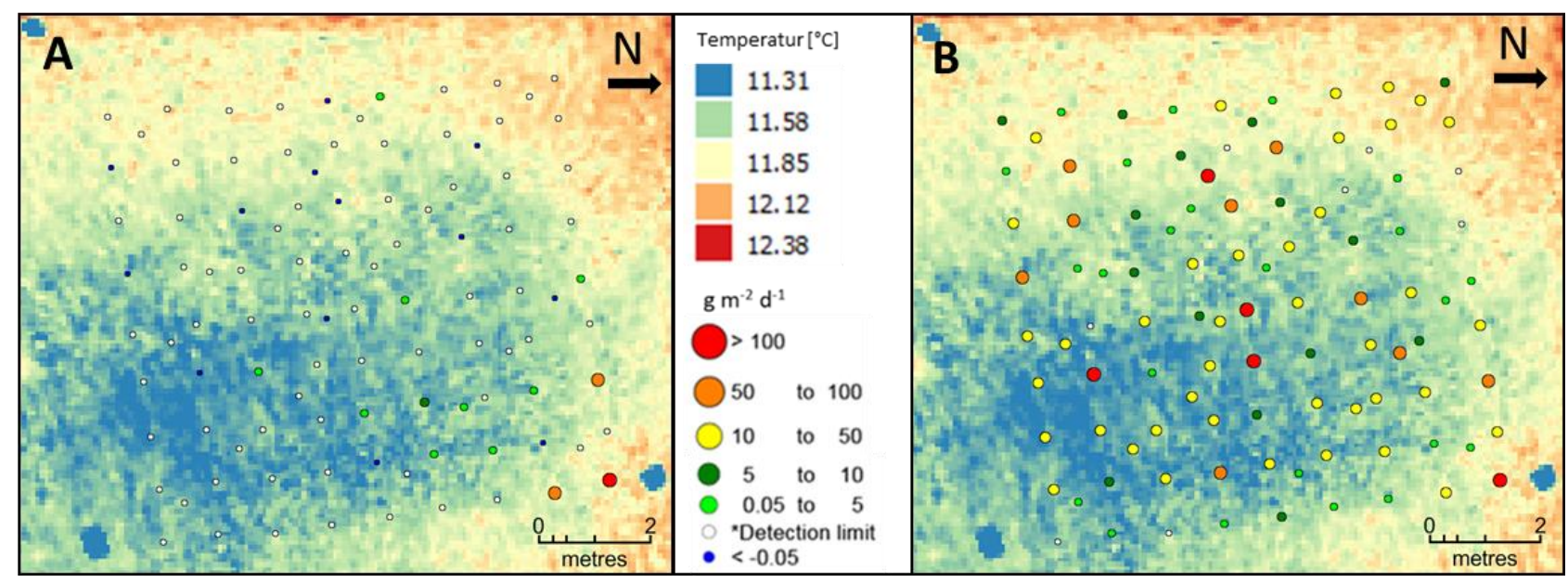

56 Fig.9. TIR image from Hedeland landfill (December $\left.10^{\text {th }}, 2015\right)$ showing surface temperature $\left[{ }^{\circ} \mathrm{C}\right.$,

57 while coloured dots represent emissions $\left[\mathrm{g} \mathrm{m}^{-2} \mathrm{~d}^{-1}\right]$ of $\mathrm{A}: \mathrm{CH}_{4}$ and $\mathrm{B}: \mathrm{CO}_{2}$. 


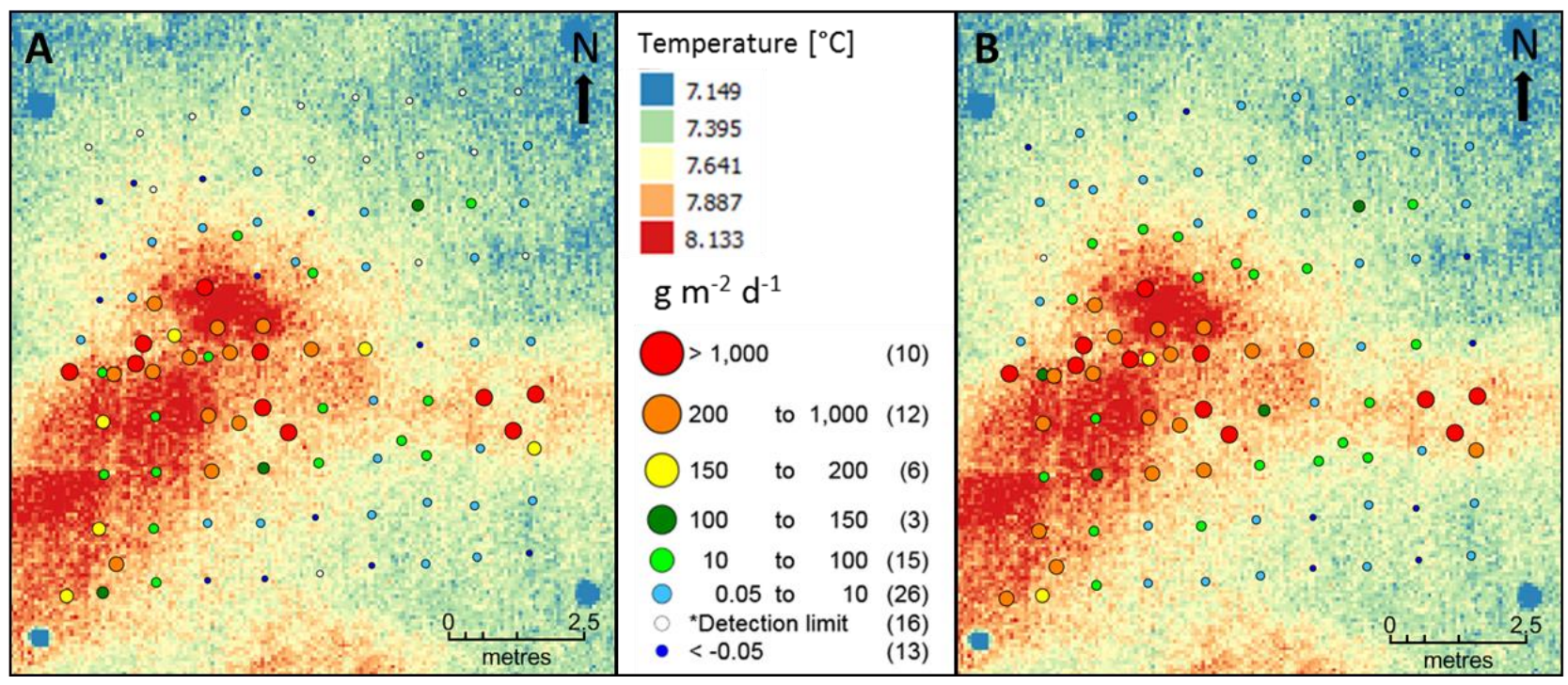

60 Fig. 10: TIR image from the Audebo landfill (March $14^{\text {th }}, 2016$ ) showing the surface temperature

$61\left[{ }^{\circ} \mathrm{C}\right]$, while coloured dots represent emissions $\left[\mathrm{g} \mathrm{m}^{-2} \mathrm{~d}^{-1}\right]$ of $\mathrm{A}: \mathrm{CH}_{4}$ and $\mathrm{B}: \mathrm{CO}_{2}$. 


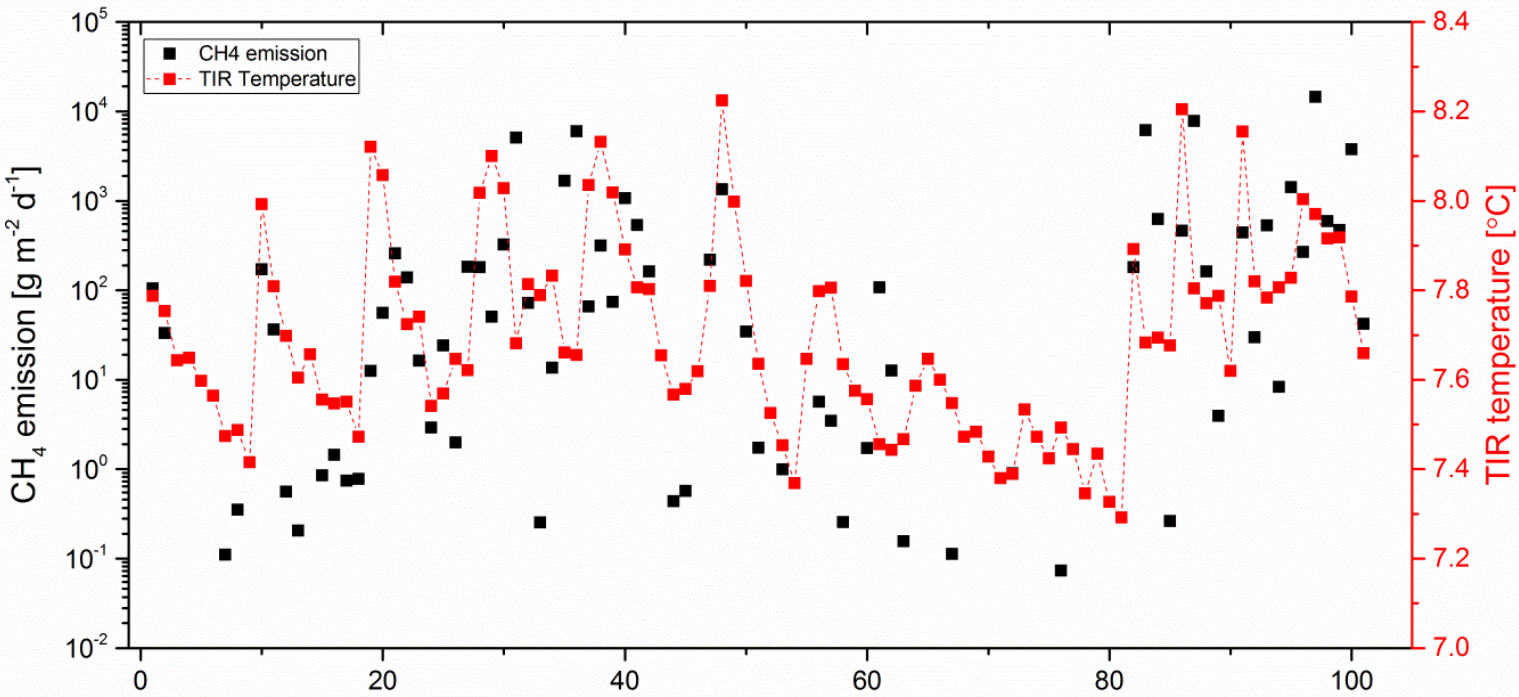

Fig. 11: Comparison of $\mathrm{CH}_{4}$ emissions and temperatures from $\mathrm{TIR}$ images at the Audebo landfill for each of the 101 measuring points (March $14^{\text {th }}, 2016$ ). NB. The emission on the left $y$-axis is logarithmic and the negative emissions is missing in the graph. 


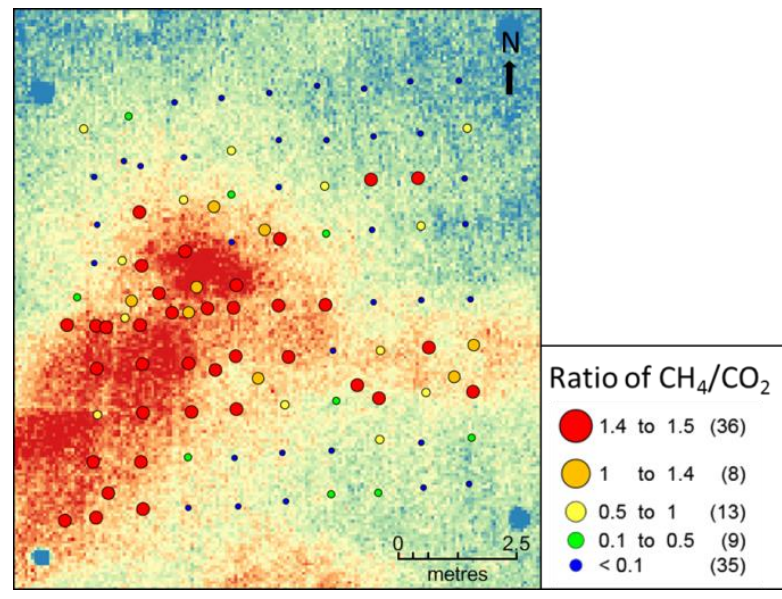

69 Fig. 12: TIR image of the test area at the Audebo landfill (March $14^{\text {th }}, 2016$ ), with $\mathrm{CH}_{4} / \mathrm{CO}_{2}$ ratios represented as coloured dots. $\mathrm{CH}_{4} / \mathrm{CO}_{2}$ ratio of raw gas was 1.49 .

71 


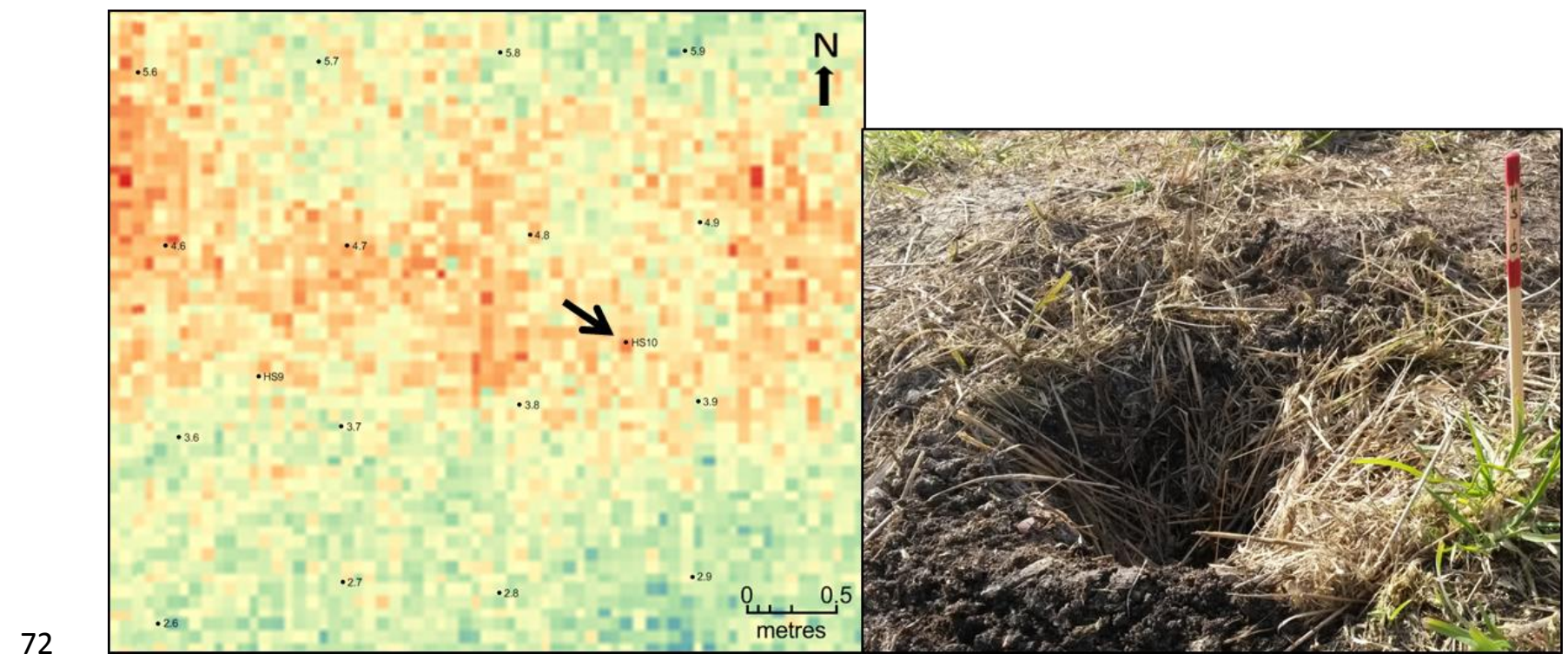

73 Fig. 13: RGB image of HS10 and a zoom of the TIR image. The black arrow indicates the location of

$74 \mathrm{HS} 10$.

75 


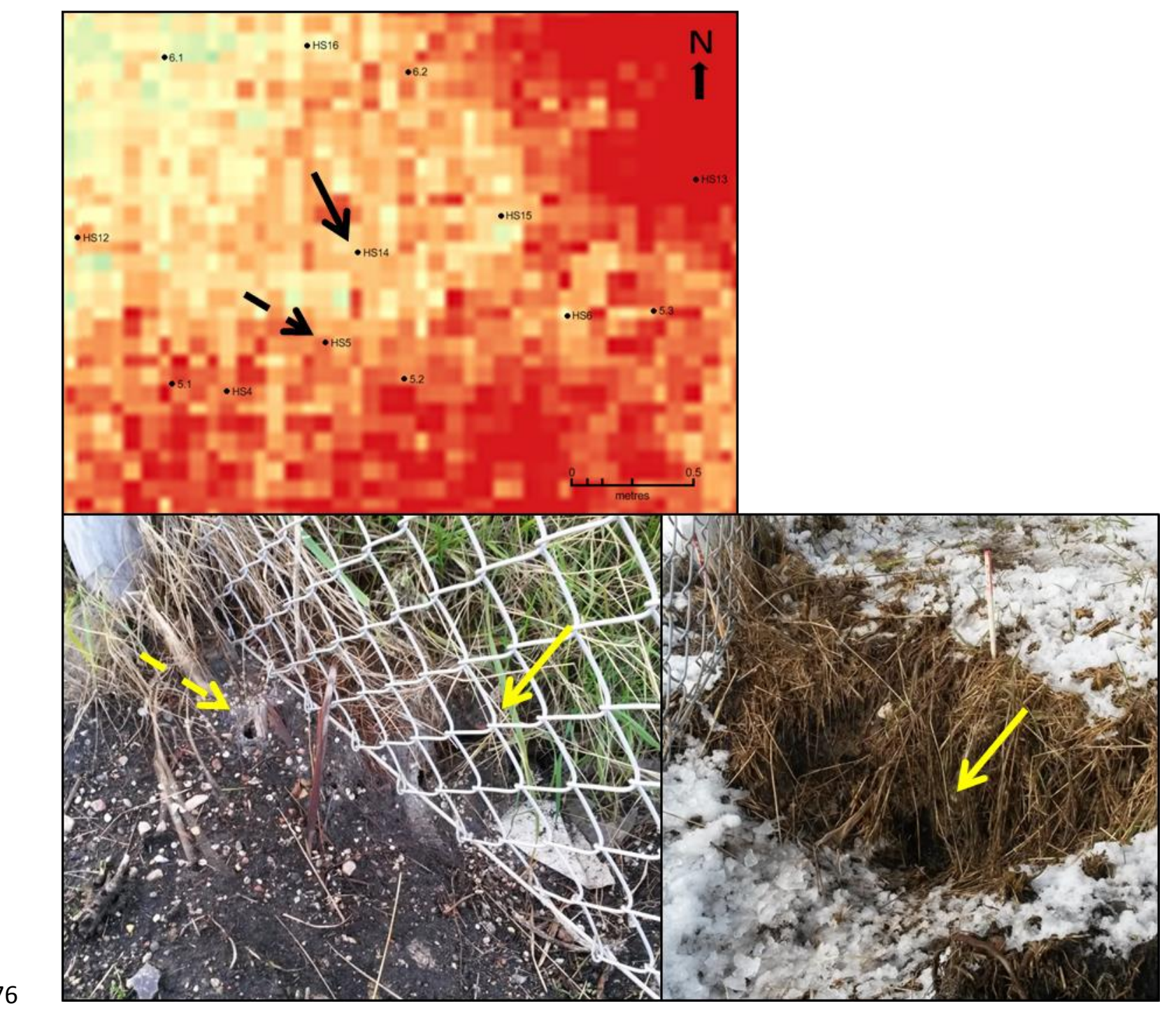

77 Fig. 14: RGB image and zoom of the TIR image. Arrows indicate the location of HS5 (dashed lines)

78 and HS14 (solid lines). 